\title{
Portomesenteric vein gas with pneumatosis intestinalis: successful conservative treatment
}

\author{
Min Sung Kim (D) , ${ }^{1}$ Jinsung Kim, ${ }^{2}$ Kwanghyun Cho, ${ }^{2}$ Heebum Yang (D) ${ }^{2}$
}

\begin{abstract}
${ }^{1}$ Surgery, Nowon Eulji Medical Center, Eulji University, Seoul, The Republic of Korea ${ }^{2}$ Emergency Medicine, Nowon Eulji Medical Center, Eulji University, Seoul, The Republic of Korea
\end{abstract}

\section{Correspondence to Dr Heebum Yang; \\ heebeom@gmail.com}

Accepted 13 January 2021

\section{DESCRIPTION}

Portomesenteric vein gas (PVG) refers to the condition where gas is observed in the portal vein and mesenteric vein radiologically. PVG has been described most commonly in patients with severe symptomatic intra-abdominal necrosis. Pneumatosis intestinalis (PI) is most commonly seen in acute bowel ischaemia. When PVG with PI is present with clinical suspicion of intra-abdominal necrosis due to acute bowel ischaemia, surgery is indicated. We report a rare case of a patient with PVG with PI conservatively treated with success.

A 53-year-old chronic schizophrenic male patient was referred to the emergency department for vomiting and bloating from a psychiatric hospital. The symptoms began with epigastric pain after lunch the day before, and thereafter, bloating occurred. The patient did not pass any gas after the onset of symptoms. The patient had no abdominal surgery history and other medical histories except schizophrenia. The vitals were blood pressure of $102 / 70 \mathrm{mmHg}$, heart rate of 130 beats/ $\mathrm{min}$, respiratory rate of 31 breaths/min, and body temperature of $36.7^{\circ} \mathrm{C}$. The patient's abdomen was distended; tympanic sound was heard throughout the abdomen; and tenderness was present over the whole abdomen. Blood work results identified a white blood cell count of $20160 / \mu \mathrm{L}$ and creatinine $1.93 \mathrm{mg} / \mathrm{dL}$. Small bowel distension was observed in the abdominal X-rays. Levin tube was inserted and brown-coloured gastric contents were drained. Abdominopelvic CT was taken, where PI in the duodenum and jejunum, with intraluminal venous gas in the intrahepatic portal vein and left portal vein branch, was observed (figures 1-3), which suggested mechanical small bowel ileus.

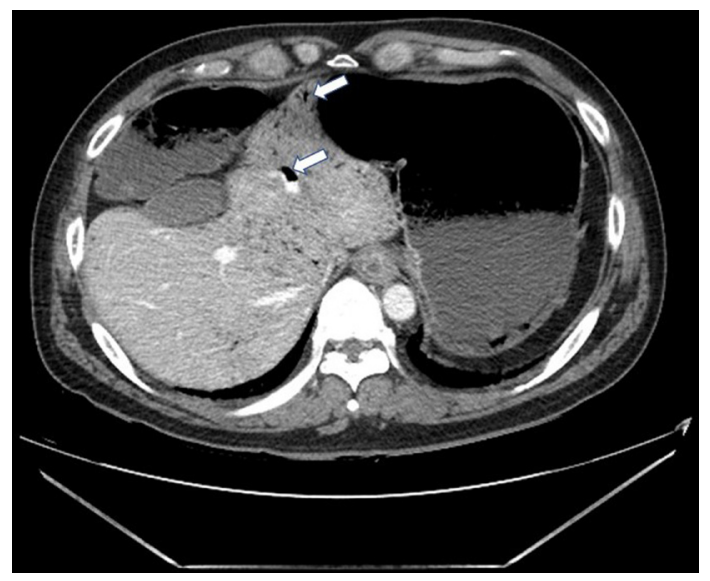

Figure 1 Intraluminal venous gas in the left intrahepatic portal vein (white arrows).

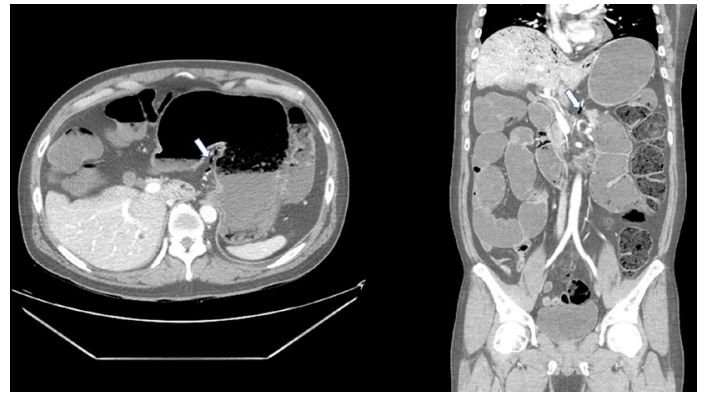

Figure 2 Intraluminal venous gas in the left gastric vein (white arrow).

Surgical consultation was seen, but since no leading point can be observed, they concluded mechanical ileus was unlikely. The patient was admitted to the intensive care unit (ICU). Fasting was maintained with Levin tube drainage and adequate hydration. Esophagogastroduodenoscopy (EGD) the day after hospitalisation revealed no specific findings except diffuse hyperemic erosion in the stomach's greater curvature. On the fourth ICU day, there was an improvement in the patients' conditions without further problems, so the patient was moved to the general ward. On the 25 th hospital day, he was discharged without any complications.

PVG is thought to be caused by intestinal wall alteration, bowel distention and intra-abdominal sepsis. ${ }^{1}$ Bowel distention can produce minimal mucosal disruption that allows intraluminal gas to become intravascular. The most common cause of PVG is bowel ischaemia. PVG resulting from bowel ischaemia has been shown to have a poor prognosis, with a high mortality rate. ${ }^{2}$ When CT demonstrates PVG and clinical findings suggest the presence of mesenteric ischaemia, surgery is thought to be mandatory.

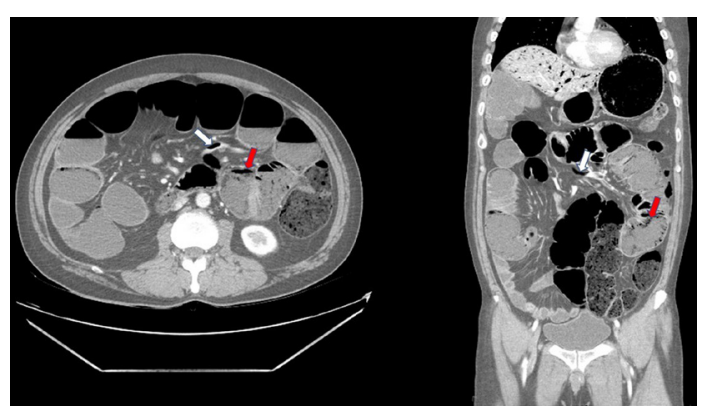

Figure 3 Intraluminal venous gas in the SMV branch (white arrows), pneumatosis intestinalis of the jejunum (red arrows). SMV, superior mesenteric vein. 
Among the cases reported as PI, there are cases involving drugs. Intestinal wall alteration and PVG may also be seen after chemotheraphy. ${ }^{4}$ In our case, ileus was thought to have been caused by anticholinergic properties of drugs taken for chronic schizophrenia, which lead to bowel distention and bowel ischaemia, which caused intestinal wall alteration and PI, and finally PVGs. In the light of liberal use of CT, a larger portion of PVGs are found with variable prognosis. Like our patient, not all PVGs require surgical intervention.

\section{Learning points}

- The most common cause of portomesentric vein gas is bowel ischaemia with poor prognosis and high mortality.

- Liberal use of CT scans revealed a larger portion of portomesentric vein gases with variable prognosis.

- Not all patients with portomesentric vein gas require surgical intervention.

Contributors MSK, JK and HY performed history and examination, acquired diagnostic data and studies, prepared the manuscript and images, and reviewed the literature. HY designed the treatment plan. MSK, KC and HY wrote and edited the manuscript and prepared the learning points. $\mathrm{HY}$ prepared the final version and approved the manuscript.

Funding The authors have not declared a specific grant for this research from any funding agency in the public, commercial or not-for-profit sectors.

Competing interests None declared.

Patient consent for publication Obtained.

Provenance and peer review Not commissioned; externally peer reviewed.

\section{ORCID iDs}

Min Sung Kim http://orcid.org/0000-0001-6370-7239

Heebum Yang http://orcid.org/0000-0001-5516-2523

\section{REFERENCES}

1 Sebastià C, Quiroga S, Espin E, et al. Portomesenteric vein gas: pathologic mechanisms, CT findings, and prognosis. Radiographics 2000;20:1213-24.

2 Wayne E, Ough M, Wu A, et al. Management algorithm for pneumatosis intestinalis and portal venous gas: treatment and outcome of 88 consecutive cases. J Gastrointest Surg 2010;14:437-48.

3 Higashizono K, Yano H, Miyake O, et al. Postoperative Pneumatosis intestinalis (PI) and portal venous gas (PVG) may indicate bowel necrosis: a 52-case study. BMC Surg 2016;16:42

4 Ozturk M, Camlidag I, Nural MS, et al. A rare cause of acute abdomen in the ED: chemotherapy-induced Pneumatosis intestinalis. Turk J Emerg Med 2017;17:151-3.

Copyright 2021 BMJ Publishing Group. All rights reserved. For permission to reuse any of this content visit

https://www.bmj.com/company/products-services/rights-and-licensing/permissions/

BMJ Case Report Fellows may re-use this article for personal use and teaching without any further permission.

Become a Fellow of BMJ Case Reports today and you can:

- Submit as many cases as you like

- Enjoy fast sympathetic peer review and rapid publication of accepted articles

- Access all the published articles

Re-use any of the published material for personal use and teaching without further permission

\section{Customer Service}

If you have any further queries about your subscription, please contact our customer services team on +44 (0) 2071111105 or via email at support@bmj.com.

Visit casereports.bmj.com for more articles like this and to become a Fellow 